\title{
NMES
}

New Middle Eastern Studies

ISSN: 2051-0861

Publication details, including guidelines for submissions:

https://journals.le.ac.uk/ojs1/index.php/nmes

\section{A Critical View of the Scholarly Discourse on the Israeli-Palestinian Problem}

Author(s): Berdal Aral

To cite this article: Aral, Berdal (2018) "A Critical View of the Scholarly Discourse on the Israeli-Palestinian Problem”, New Middle Eastern Studies 8 (2), pp. 46-67.

Online Publication Date: 11 January 2019

\section{Disclaimer and Copyright}

The NMES editors make every effort to ensure the accuracy of all the information contained in the journal. However, the Editors and the University of Leicester make no representations or warranties whatsoever as to the accuracy, completeness or suitability for any purpose of the content and disclaim all such representations and warranties whether express or implied to the maximum extent permitted by law. Any views expressed in this publication are the views of the authors and not the views of the Editors or the University of Leicester.

Copyright New Middle Eastern Studies, 2019. All rights reserved. No part of this publication may be reproduced, stored, transmitted or disseminated, in any form, or by any means, without prior written permission from New Middle Eastern Studies, to whom all requests to reproduce copyright material should be directed, in writing.

\section{Terms and Conditions}

This article may be used for research, teaching and private study purposes. Any substantial or systematic reproduction, re-distribution, re-selling, loan or sub-licensing, systematic supply or distribution in any form to anyone is expressly forbidden.

The publisher does not give any warranty express or implied or make any representation that the contents will be complete or accurate or up to date. The accuracy of any instructions, formulae and drug doses should be independently verified with primary sources. The publisher shall not be liable for any loss, actions, claims, proceedings, demand or costs or damages whatsoever or howsoever caused arising directly or indirectly in connection with or arising out of the use of this material. 


\title{
A Critical View of the Scholarly Discourse on the Israeli- Palestinian Problem
}

Berdal Aral ${ }^{*}$

\begin{abstract}
The scholarly discourse about Israel has at least two defects. First, although it is a colonial-settler state that has occupied the entirety of the former British Mandate of Palestine, it is still by and large treated as a "normal" state in the literature; and secondly, even the progressive scholars - who are very critical of Israel for is subjugation of Palestinian rights and massive breaches of human rights - have mostly confined their critique to the Palestinian territories occupied during the 1967 War. Therefore, the progressive scholarship ought to adopt a wider view of Israel's irregular practices by extending its focus to the entirety of territories corresponding to the former Mandate of Palestine and the entirety of the history of the state of Israel in the context of its occupations, colonial policies, ethnic cleansing, population transfers, systematic racism and massive human rights violations against the Palestinian people. This "new" approach also requires, at least in the context of critical academics, an advocacy for multiple sanctions by international institutions, first and foremost, by the United Nations (UN), to be imposed against Israel as was the case with the Apartheid state of South Africa during the Cold War.
\end{abstract}

Keywords: Zionism; Palestine; Israel; Colonial-Settler State; Palestinian Self-Determination; Critical Scholars; Occupation; Racism; Oslo Process; Two-State Solution; Palestinian Scholars

\section{Introduction}

The Israeli-Palestinian conflict/problem is an epitome of the failure of the existing world order which continues, largely, to be attached to a partial and imperial interpretation of international law. Possibly no other case can better unveil the moral aloofness, lack of consistency and hypocrisy of the present world order and international legal process than the terrible tragedy which the Palestinians have suffered for almost one hundred years as victims of Zionism. The problem is the persistent failure of international institutions and mechanisms to deliver a viable, sustainable and reasonably fair solution to the Palestinian problem. The Palestinian tragedy is a testimony to the fact that, in matters concerning "high politics" issues that strongly hinge on the national interests of powerful actors, existing international mechanisms tend to fail to differentiate between the oppressor and the oppressed, particularly

*Berdal Aral; Department of International Relations, Istanbul Medeniyet University, Dumlupınar Mahallesi, D100 Karayolu No:98, Kadikoy, Istanbul 34000, Turkey. Email: baral72@gmail.com. 
when the oppressor is a Western state or a Western ally, and, the oppressed, a non-Western actor.

However, given gravity of its consequences, the Israel-Palestinian conflict should be a key concern of international society and ought to be resolved within the rubric, first, of the UN (United Nations). The urgency of the problem emanates from a number of factors: first, because, the Palestinian problem is the "mother of all problems" in the Middle East and the Muslim world which is causing enormous desperation and fury among the people in this part of the world; second, because, both the "Palestinian problem" itself and Israel's overall aggressive policies towards the surrounding states are threatening regional stability and international peace and security. We ought to bear in mind that the goal of maintaining international peace and security is the main raison d'être of the UN; third, because Israel's emergence as a state and its rise into a regional power owes a great deal to the global hegemonic order which figured, first, under the leadership of Britain when it assumed mandatory power in Palestine after the First World War and, then, of the US (United States) after the Second World War. These two states have acted as the patron-protectors of the Zionist movement from the early $20^{\text {th }}$ century onwards.

Although these are known truths for many, nonetheless, prominent states such as the US, Britain, Russia and China, leading international institutions such as the UN, and even critical international politics and law scholars to this day continue to treat this complex and perilous problem in a way that diminishes its gravity. The Israeli-Palestinian problem calls for a sophisticated and comprehensive strategy as well as a genuine commitment and determination for effective action. The failure of international society to adopt a holistic approach to this grand problem has only served to reduce its effectiveness in the face of Israeli territorial expansionism, unlawful killings and systematic racism against the Palestinians. The most appropriate context in which to understand Israel, the culprit of a regional as well as a global problem, is its persistent and unmitigated colonial-settler aggression against the Palestinian people in an age that prides itself, inter alia, with sending colonialism into the dustbin of history. Furthermore, disregarding the colossal mix of legal and political disputes emanating from the Zionist project to establish a Jewish state in Palestine and its seizure of large chunks of the Palestinian territory even before the 1967 War, and instead confining legal discussions only to the Israeli occupation, in 1967, of the remaining 22 percent of the Mandate of Palestine as the last remains of the territory belonging to the Palestinians and to the illegally built Jewish settlements in the West Bank and East Jerusalem, is both a lack of sensitivity towards historical injustices committed against the Palestinian people and a symptom of the failure of the world order in terms of finding a fair and sensible solution to this souring problem.

The major actors of the world order in the immediate aftermath of the Second World War, namely the US, Soviet Union, Britain, France and the UN, apparently turned a blind eye to the unscrupulousness and the far-reaching compass of the Zionist project when Israel was founded in 1948. Unfortunately, the same disregard about Zionist ambitions plays itself out today. The depth of the problem with Israel, as concerns the Palestinians, is at least threefold: firstly, the problem unfolds in terms of temporality by virtue of being a hundred years' problem; secondly, Israel - since its foundation - has committed countless crimes and 
injustices against the Palestinian people ${ }^{1}$; thirdly, Israel was and still is a colonial-settler state that wishes to possess the entirety of former Mandate of Palestine by force.

However, it is not only the world order or the dominant actors in international society that tend to disregard the whole compass of Israel's aggressive ambitions. The scholarly literature dealing with the Israeli-Palestinian problem has also displayed similar tendencies to "minimize" the context and substance of the Israel-Palestinian problem. Furthermore, from the foundation of Israel up to the present period, the prevailing literature on the IsraeliPalestinian problem has tended to lay excessive emphasis on Israel's security concerns and priorities, while the plight of the Palestinians is mostly dealt with in the context of territories occupied by Israel in the 1967 War, namely West Bank (including East Jerusalem) and Gaza. The docility of international scholarship, including the critical/progressive ones, is truly astonishing given that many unorthodox observers and scholars of the Palestinian tragedy consider themselves as "pro-Palestinian" on account of the suffering of this hapless people.

Today, a great part of prominent international actors as well as critical/progressive scholars continue to repeat the mantra of the "two-state solution" as the main framework for the solution of the Palestinian problem although, first, the so-called "(Oslo) peace process" has now become a matter of history because of Israeli intransigence, and, second, the integrity of the territory over which the Palestinian state would be supposedly built has already been broken by Israel through expropriation and other means to such an extent that, if the current fragmentation continues, soon there will be no territory left on which the state of Palestine could possibly be established. As if this were not the case at the moment, the discourse within the UN and among the group of critical/progressive scholars sympathizing with the Palestinians continue to pay lip service to the "two-state solution" without sufficiently critiquing the overall context of Israeli aggression.

This article is not intended to be a polemical piece which seeks to take issue with some scholars and journals for the purpose of, possibly, condemning or putting blame on the authors of certain views and approaches. This study is likewise not designed to be a literature review on the Israeli-Palestinian problem. Instead, without mentioning specific names and studies, it critiques the overall methodological and substantive approach of the bulk of "critical scholars" to the Israeli-Palestinian problem. In this study, I consider "critical/progressive scholars" and publishing outlets as those who sympathise with the victimhood of the Palestinians, are critical of various Israeli practices intended to subdue and marginalize the Palestinians, and support the legal and political rights of the Palestinian people. As such, they challenge the established views and approaches dictated by the overwhelming power of Israel, the unbridled support of the US for Israel, and the hegemonic pro-Israeli narrative within the existing global system as expressed through the decisions and the overall posture of global actors and international institutions. The "critical/progressive" outlets include international social science journals with socialist/left-wing orientation, the journals specialising in issues of justice and peace, and those that advocate unorthodox views on major issues and problems in the world. In my own classification, "critical" scholars also include individual scholars, although not necessarily belonging to the left of the political spectrum, who may for whatever reason sympathise with Palestinian victimhood and search for self-determination. The "critical outlets" also include human rights groups, peace activists, and civil society initiatives advocating a more egalitarian and just international 
order. The views of critical scholars are, of course, mainly expressed through books, articles, reports, conference/seminar presentations, and op-eds; these materials are also among the main sources of the views and discussions which I articulate in this study.

This article, following the Introduction, first draws on the current state of (international) scholarship and academic discourse with regard to the Israeli-Palestinian problem. Then, it continues with an attempt to answer the following question: how "critical" are the so-called "critical scholars" in regard to the Palestinian problem? Next, this piece seeks to bring into focus the close resemblance between Zionism and South African Apartheid in terms of their racist practices and segregationism. After this, the article tries to find out the way in which the Oslo (Peace) Process, which began in 1993, was perceived by critical scholars. This study then proceeds with an argument about the absurdity of treating Israel as a "normal" state, although this is how the existing scholarship, including most of critical scholars, conceives of Israel. After this, the article draws on the "drama" of the Palestinian scholars since they appear to be mostly isolated in their struggle to break with the parochial confines of the aforementioned prevailing international discourse on the IsraeliPalestinian problem. This study concludes with some critical remarks about the limited nature of the scholarly discourse on the Palestinian problem which, it argues, is informed largely by power politics and expresses the need to adopt a more comprehensive notion of Palestinian self-determination as a struggle for emancipation from the colonial-settler state of Israel.

\section{The Current State of Scholarship and Academic Discourse in regards to the Israeli- Palestinian Problem}

One of the main problems within the existing literature on the Israeli-Palestinian problem is its overall disregard for the legally problematical origins of the state of Israel. That the Zionists have come to impose themselves - by force and international trickery - in the Mandate of Palestine and has since been officially recognized by a great majority of states, does not necessarily render Israel "legitimate" (Varol 2009: 25). "Israel" is not the name of a territory; it is rather the name of a "state" that has occupied and usurped the land of the Palestinians. Therefore, it is perfectly conceivable to reject the legitimacy of the state of Israel (Varol 2009: 29).

There are strong grounds to assume that the whole enterprise of the partitioning of Palestine between Jews and Arabs, which was the end-product of massive Jewish migration into the Mandate of Palestine at the expense of its Arab inhabitants, was illegal. The Jewish migration was against the wishes of the native inhabitants of the territory, the Palestinian people. Besides, the UN Charter does not necessarily confer on the UN General Assembly the right to partition a given territory, which was the case for Resolution 181 of November $1947 .^{2}$ It follows that the birth of Israel and its seizure of Palestinian settlements by military force were likewise breaches of international law. Indeed, there is ample scope to proceed with this type of legal reasoning. We could begin by noting that the Joint Declaration which was signed between Britain and China in 1984, providing for the return of Hong Kong previously taken by Britain as a colonial enclave - from the British to the Chinese sovereignty, did not in any way hint about the Chinese recognition of the 1842 Treaty of 
Nanking which was the original treaty registering British sovereignty over Hong Kong (Carty 2013: 176). If international law is not necessarily a complete and determinate legal system, which cautions us about its purely positivistic character, the same applies to the system of international law as it stood immediately after the Second World War and even after the end of the Cold War. This suggests that the recognition of the basis of the establishment of the "state" of Israel as "legal" simply because the British colonial administration in Palestine possessed the legal title to it and thus enjoyed the requisite authority to legally permit Jewish migration into Palestine is only one possibly "interpretation" of international law among many other possible interpretations. There is no reason why one cannot pose questions of a legal nature that could not challenge the legality of the process leading to the foundation of the Israeli state and its territorial possessions. Such are the questions and points raised by Carty (2013: 176-177) for instance:

[W]hether the principle of self-determination was recognised as binding at the conclusion
of World War One, so that it should have been incorporated in the Palestine Mandate;
whether, consequently the Palestine Mandate violated the principle of self-determination
and the League of Nations failed to uphold it; whether the Jewish/Israeli political and
military operations in the Mandate and later Israel during the civil conflict within the
Mandate and during the international war up until Armistice Agreements were signed,
constituted a violation of the principle of self-determination as applied to the Palestinian
people; whether, consequently, the State of Israel came into existence in violation of the
principle of the self-determination of the Palestinian people; whether, in the alternative,
the international community has recognised the existence of the State of Israel as an
accomplished fact.

The array of questions that could be raised in regards to the Israeli-Palestinian problem might possibly be extended even further. Indeed, there are a great number of pertinent questions which the dominant international legal doctrine has chosen to gloss over: First, does Israel have a legal right of existence as a state? Second, are the current boundaries of Israel "legal" under international law? Third, is Israel a "settler-colonial state"? If indeed it is, are we not under a legal and moral duty to accept that the Palestinian right of self-determination should be applicable to the entirety of the Mandate of Palestine? This article thus pursues an unorthodox line of argument, while at the same time critiquing the international scholarly discourse on the Palestinian problem.

We could begin with a definition of Zionism as it came to impose itself in the Mandate of Palestine after the First World War. A useful description of this nationalist ideology is made by Garaudy (1996: 25):

An internal policy based upon racism; an external policy of aggression and expansion aimed at the conquest of "living space" to accommodate a hypothetical immigration; and a method of political action typified by state terrorism.

Zionists and the Zionist ideology were hostile towards the "natives" of Palestine right from the beginning. Zionists considered themselves ethnically, culturally and politically superior to the peoples inhabiting the Middle East. The Zionist leadership were also unwavering about their single-minded determination to supplant the Arab inhabitants of Palestine with Jews, to the extent that this was possible. The history of Israel is a testimony to the step-by-step 
realisation of the Zionist project, inter alia, by the blatant use of force and mass expulsions of Palestinians from their whereabouts. This brings us to the colonial nature of the state of Israel. Zureik (2016: Preface) notes that colonialism rests on three pillars, namely "violence, territory, and population control". All three involve racism and a racist narrative. Zionism falls into the framework of "settler colonialism" as it likewise manifests itself in strategies such as violence, repression and racialist surveillance against Palestinian Arabs (Zureik 2016: Preface). To be more specific, the Zionist settler colonialism that led to the foundation and, then, the expansion of the state of Israel has been practiced through "expulsion, seizure of land, and displacement of the indigenous population" (Zureik 2016: 69).

The case of the Palestinian tragedy as an instance of settler-colonialism was and still is accurately perceived by peoples of Asia and Africa whose countries had been colonized by European powers. The "native" victims of colonial subjugation were ethnically and culturally dehumanized as "inferior". This claim about the inferiority of the indigenous people was a common narrative in the $19^{\text {th }}$ century - deployed as a useful cloak to justify "the scramble" for new colonial possessions beyond Europe. This hurried race for territorial acquisition among European powers largely coincided with the Zionist zeal to penetrate into Palestine in the latter part of the $19^{\text {th }}$ century as noted by Edward Said (1979: 22-23):

...it is important to remember that in joining the general Western enthusiasm for overseas territorial acquisition, Zionism never spoke of itself unambiguously as a Jewish liberation movement, but rather as a Jewish movement for colonial settlement in the Orient.

It is thus clear that Zionism is not simply an instance of a fractional occupation of a piece of territory, overwhelmingly inhabited by Palestinian Arabs, which constitutes only a part of Mandate of Palestine. Disappointingly, this is how even many scholars who strongly sympathise with the Palestinians as victims of Zionism view the issue. The truth of the matter is that Zionism is a case of deepening colonialism in an age that has seen the dismantlement of the last remnants of Western colonialism when the Portuguese colonial possessions in Africa, as well as the settler-colonial countries, namely Rhodesia and South Africa, were being liberated from colonialism from the 1970s onwards. This leads Massad to draw on the tensions inherent in the psychological and political milieu in which the state of Israel operates: 'The jingoistic nationalism of Israeli society, its high militarization, and its racially supremacist ideology masks an increasing anxiety about its place in the world" (Massad 2006: 177). Today, the ongoing plight of Palestinians in the former Mandate of Palestine is a clear indication that Israel is indeed a settler-colonial state. The Palestinians living in the Palestine territory today can be grouped into three categories - none of which has anything to do with the contemporary legal principles of equality before the law and non-discrimination: racially discriminated Palestinians with citizenship within Israel; those living in the West Bank under military occupation; those who are under a deadly blockade in Gaza.

As if to deny the massive historical injustices committed against the Palestinians by the Zionist movement and the state of Israel, in the West, the academic discourse on the IsraeliPalestinian problem is replete with views that greatly favour Israeli priorities: strong emphasis on Israel's "security concerns"; occasional reference to the UN Security Council resolutions; and a mild criticism of Israel for its "disproportionate use of force" against the 
Palestinians. When and if the view voiced in the West is sufficiently critical, it is almost always the objection to Israel's "continued occupation of the post-1967 territories". Wider issues which are particularly related to the colonial-settler nature of Israel have mostly been swept under the carpet by the majority of scholars, the media and observers. Gramsci elucidates that hegemony is not produced solely by force and domination, but also, inter alia, through the consent of intellectuals. ${ }^{3}$ Apart from (mostly left-wing) critical scholars whom we shall turn later, in the course of the formation of the Zionist entity in Palestine, Western liberals and the Zionists largely converged in ignoring the existence of Arabs in Palestine. For liberals, Israel represented reason, enlightenment and idealism; therefore, the Zionists deserved to have a rightful claim to the entire Palestine. Palestinians, by contrast, being "backward and inferior", were simply conceived as nonpersons (Said 1979: 37-38). Not much has changed since. Today, even the "liberal" American media is less critical of Israel than certain parts of the Israeli media and intellectuals. Although it is common knowledge that the prospect of a substantial change would not possibly come about without the US pressure on Israel, scholarly discourse in the US about the Palestinian problem is very much dominated by an obvious pro-Israeli bias and the silencing of Palestinian voices to a large extent (Slater 2007: 85).

The crux of the problem with the present orthodoxy is its treatment of the Palestinian problem within a parochial framework that emphasizes Israeli "human rights violations" against the "minority" called "Palestinians" and/or, if at all, the rights of a people who are entitled to have their own state within a very small fraction of the former British Mandate of Palestine. Salamanca incisively asserts that the contemporary literature on the Palestinian problem is dominated by micro-political analysis or Israeli state practices that give harm to the Palestinian inhabitants in a specific issue area. Alas, this is far from being a genuine liberationist reading of the modern Palestinian history. As a challenge to the existing discourse on the Palestinian problem, the "liberationist" or "new" scholarship has been seeking to find a niche for Palestinians within an internationally recognized colonial structure which we call Israel. In such an intellectual milieu in which the "new" scholarship is only a minor exception, "it is not surprising that even scholarship written in solidarity with Palestinians tends to shy away from structural questions" (Salamanca et al. 2012: 3).

\section{How "Critical" are Critical Scholars on the Israeli-Palestinian Problem?}

Most of the critical scholars writing on the Israeli-Palestinian problem are satisfied with only a partial solution to the Palestinian problem without questioning the whole paradigm about Israel's origins, status and place in the world. The partiality of views and the widespread failure to propose unorthodox formulas for peacefully resolving the Palestinian problem could possibly be related to some of the hegemonic aspects of international law, of which Israel is one of the beneficiaries.

International law is, inter alia, a culture of defining and solving legal problems in a way that often suits the powerful. It operates both as a context and as culture that impact on the modality of the solutions that actors favour. Rules and meanings are conceived in ways that often overlap with the hegemonic interests of the powerful. Chimni (2006: 15) argues 
that international law formulates certain ideas in the shape of rules which are likely to serve the interests of the powerful. As he sees it, "international law... represents a culture that constitutes the matrix in which global problems are approached, analyzed and resolved". This culture is shaped and framed by the dominant ideas/discourses of the time.

Perceptions of international law are strongly influenced by international institutions which tend to give legitimacy to the prominent norms within the world order and domesticate or repress counter-hegemonic approaches. These institutions establish a framework for discussions in a way that lean towards insuring that legal norms serve the interests of powerful actors. Again, as noted by Chimni (2006: 15-16), "the knowledge production and dissemination functions of international institutions are... steered by the dominant coalition of social forces and States to legitimize their vision of world order". Therefore, it is not surprising to observe, as Rajagopal argues, that prominent international mechanisms, such as the UN Security Council, strengthen the hegemonic complexion of international law (Rajagopal 2006: 781). In such an international legal and institutional milieu, with its multiple processes and mechanisms for securing consent, for scholars to keep away from the recognized boundaries of the existing discourse, as in the case of the Palestinian problem, may be exceedingly difficult.

Although not to the same degree as mainstream scholars, most critical scholars seem to have been "tamed" by group pressure in order that they conform to the boundaries of the discursive convention on the Israeli-Palestinian problem. Generally speaking, scholars are often constrained by the dominant ideas about thinking, writing and envisioning in a particular way that are seen as the hallmark of a "good academic work". This tends to lead academics to circumvent certain ideas and propositions which fall outside of established orthodoxies and prevailing discourses in a particular social discipline. The scholars may also lose their critical faculties as a result of pressure from colleagues, as well expressed below:

A variety of social and peer pressures are brought to bear on dissenting academics to neutralize their critical energies. Even eminent personalities are unable to be bold and courageous in evaluating contemporary trends and imagining alternative futures (Chimni 2006: 22).

Interestingly, the approach of the so-called progressive/critical (Western) scholars and the Israeli "doves" are in parallel as they appear to be united in their support for the consolidation of most of the Israeli gains at the expense of the Palestinians. Both of these groups believe that their views are shaped by a "fair" and "sensible" frame of reference within which to proceed for a solution of the Palestinian problem. As they see it, this position is very much in line with the general norms of international law, human rights principles and the right of self-determination. A report written and published in 2009 by a group of Israeli scholars advocating peace with the Palestinians puts forward an interesting example about the way in which the Palestinian problem and its solution is perceived by the unorthodox Israeli academics. The report relies on a number of presuppositions, claims and propositions: Palestinians have no legal objection to Israeli sovereignty in the 78 percent of the former Mandate of Palestine; it is Israel's occupation of the West Bank (including East Jerusalem) and the building of illegal settlements thereof which is the root cause of the Palestinian problem; Palestinian violence, undesirable though, is the direct consequence of 
the Israeli oppression (Halper 2009: 4). Broadly speaking, this is also the overall framework within which the Palestinian problem is being discussed by (Western) progressive scholars in the language of international law. While strongly advocating the solution of the Palestinian problem peacefully by taking cognizance of the Palestinians' right to selfdetermination, there is no leeway in the writings of most critical scholars for any suggestion about liberating the entire Palestine territory from Israeli domination nor is there any serious commitment to the full right of return for all of the Palestinian refugees spread around the globe. Besides, in this supposedly critical literature, there is rarely any mention about holding the state of Israel accountable for its systematic and massive crimes, such as ethnic cleansing, against the Palestinian people since it came into existence in 1948. In the legal and political analyses of the "progressive" brand, there is hardly any mention, as a problem, of the Palestinian territories which fell into the hands of Israel during the Arab-Israeli War of 1948-49. In this view, the avalanche of Israeli fait accompli on the ground, if they are not about the territories occupied by Israel in 1967, ought to be seen as "irrelevant" to the final settlement between Israel and the Palestinians. The end-result of this mode of analysis is altogether an unhappy one: Disappointingly, the doctrine finds itself in the position of approving most of Israel's illegal and unjustified gains based on brute force: expulsions; illegal settlements; arbitrary laws; and persistent threats and intimidations.

There is, then, hardly any differentiation between the "doves" of the Israeli peace camp and the sympathetic "progressive" Western scholars in the way in which they define the Palestinian problem and offer a supposedly "fair" solution. The above report by Israeli scholars is an expression of how the most "progressive" voices among the Israeli peace camp conceive of the issue at hand. This is almost identical to the position of the Western scholars "supporting Palestinians". Confining the discussion about the Palestinian liberation to 22 percent of the Mandate of Palestine could be likened to a metropolitan/colonial state offering independence to the people of a colonized territory only in a small fraction of the homeland. With very few exceptions, the process of decolonization, a common occurrence in the $20^{\text {th }}$ century, did not lead to the partition of the colonized territories. The indigenous people and their leadership strongly refused the idea of dividing their territory between the colonizer and the colonized (Rouhana 2018: 655). In the specific case of Palestine, partition also suggests that "Israel would not take responsibility for the refugee problem" or "face the truth of the ethnic cleansing that occurred in 1948" (Rouhana 2018: 656). Hence, the division and destruction of the Mandate of Palestine, as the favoured formulation of the critical scholars, is both historically and morally unsustainable.

It seems that the critical scholars, dealing with the legal, political and historical dimensions of the Palestinian problem, have also been under the strong influence of the dominant international actors' - states as well as international institutions - dismissive approach to the problem. Israel is apparently conceived favourably by prominent international actors such as the US and prominent European states as a "special case" which should be treated with much delicacy. Possibly one reason why the systemic actors treat Israel as if it were a "normal" state, although it is a settler-colonial state, is, first, that the foundation of the state of Israel in 1948 is seen as the fulfilment of the prophecy in the Old Testament, and, second, it is seen as "untouchable" because its emergence is seen as the direct consequence of the Nazi genocide against the Jewish people, known as "Holocaust" 
(Welty 1984: 60-61). This privileged view of the Zionist state seems to have been duly internalized by large numbers of critical scholars too.

As such, the supposedly critical scholars have mostly avoided taking a sceptical view about Israel's "right" to exist in Palestine. They have also mostly steered clear of delving into the disturbing episodes in Israel's history; and those who did, have mostly disregarded the legal and political ramifications of this dark history for the ongoing Palestinian claims and entitlements. The critical scholars have a propensity to argue that the negotiations between Israel and the Palestinians should begin with each accepting the validity of the other's claim. ${ }^{4}$ This is, from the viewpoint of most Palestinians, is a distorted perception of the nature of the problem, because such formulations disregard the seizure of the Palestinian homeland by brute force, the continuing suffering of Palestinians at the hands of Israel, and the routinized ethnic cleansing of the Palestinians. The hard truth is that, scholarly analysis that counsel mutual conciliation between the parties as key to an eventual settlement, is "detached from power relations and illegitimate political practices, such as state-sanctioned discrimination and military occupation" (Rouhana 2018: 654).

In many instances, critical scholars, sometimes unknowingly, play into the hands of imperialism, especially in the shape of cultural imperialism. This is subtly observed by Bourdieu \& Wacquant (1999: 51):

Cultural imperialism (American or otherwise) never imposes itself better than when it is served by progressive intellectuals (or by "intellectuals of color" in the case of racial inequality) who would appear to be above suspicion of promoting the hegemonic interests of a country [and one may add system] against which they wield the weapons of social criticism.

It is telling, then, to observe that the critical scholars have mostly failed to go beyond the boundaries of the Israeli-Palestinian dispute drawn largely by power politics and/or by the concerted positions within international institutions. The posture adopted by this group of scholars is not necessarily more progressive than the position taken by, say, the EU. In a document expressing the EU views on this issue, it is said that "the legal position under international humanitarian law and the common position of the European Union is that East Jerusalem, Gaza and the West Bank essentially do not belong to Israel, are occupied territory, and should be differentiated from Green Line Israel (pre-1967 Israel)".5 By and large, progressive/critical scholars have failed to express views which are more "progressive" than the formulation put forward in the EU document. This is in a way surprising because, while the European Union is a union of states and therefore tends to adopt positions in a pragmatic fashion, academics have the freedom to take bolder and more imaginative stances on social and political issues which they investigate.

Apparently, critical scholars have mostly failed to devise imaginative ideas, concepts, structures and formulations in order to make effective and practical use of international law and international decision-making mechanisms. We could ponder over some ideas and strategies that could be propounded by critical scholars in order to exceed the parochial scope within which the Israeli-Palestinian problem is discussed. For instance, they could begin by drawing on the unilateral leverage which the US administration could utilize against an intransigent Israel. The US has numerous instruments at its disposal that it could 
deploy to impact on Israeli policies towards the Palestinians: threatening to halt economic and financial support for Israel; signalling the possibility of retracting diplomatic support; leading an international campaign to isolate Israel (Mearsheimer \& Walt 2008: 226). The mechanisms within the UN could also be taken by critical scholars as a point of reference for both describing and conceptualising the policies associated with Israel and for identifying new procedures and strategies to punish the Israeli aggression and racism. Critical scholars need reminding that Zionism very much resembles South African Apartheid policies. As is well known, the UN General Assembly, with a large margin of supportive votes, proclaimed in 1975, "that Zionism is a form of racism and racial discrimination". ${ }^{6}$ At the time, the US ambassador to the United Nations, Jeane Kirkpatrick, while disagreeing with the resolution, made a very interesting remark: "when the UN majority declared Zionism is racism, it declared immoral the foundations of Israel" (Quigley 2005: 211). No doubt, she was right!

The "critical" faculty of critical/progressive scholars has mostly been emasculated on account of the failure of most of them to open up the boundaries for discussing the Palestinian problem in order to suggest alternative definitions of the Palestinian problem and the Zionist project, a linkage between Palestinian struggle and other liberationist movements, and imaginative prescriptions that go beyond the dictates of the current status $q u o$ as defined by Israel and the hegemonic world system. As a result, most of the advocates of Palestinians belonging to critical scholarship have failed to play a "progressive" and/or emancipatory role in the context of the Palestinian problem.

\section{Close Resemblance between Zionism and Apartheid}

There are striking similarities between Israel's policies towards the Palestinians and South Africa's former Apartheid system which remained prevalent during the Cold War and was eventually dismantled in 1994. This is particularly true of the way in which Israel has treated the inhabitants of territories which fell under its occupation after the 1967 War. There are many instances of Israeli practices that are reminiscent of the Apartheid regime: the separation wall; illegal and ever-expanding Jewish settlements; roads exclusively built for Jewish use; etc. It is even possible to claim, as some do, that Israel's racialist policies against the Palestinians are in many respects more harmful and thus "worse than" that of the South African system of Apartheid (Dugard and Reynolds 2013: 912; Zureik 2016: 77). The degree of the oppression of Palestinians is such that Israel, as the victimiser, is today fearful of the Palestinians' revenge and retribution. Due to this, it has come to "securitize" almost everything associated with the Palestinians: "Demography, Arab-owned lands, Arab Palestinians moving and crossing borders, political dissent, certain forms of knowledge, speech, memory and the relationship to the past" (Esmeir 2004: 3).

Israel's systematic racism against the Palestinians was fully recognized by the Russell Tribunal on Palestine which was assembled in 2011. This tribunal, a civic initiative devoid of legal force, concluded that Israel was an apartheid state:

The Tribunal finds that Israel subjects the Palestinian people to an institutionalised regime of domination amounting to apartheid as defined under international law... The Palestinians living under colonial military rule in the Occupied Palestinian Territory are 
subject to a particularly aggravated form of apartheid. Palestinian citizens of Israel, while entitled to vote, are... subject to systematic discrimination across the broad spectrum of recognised human rights. Irrespective of such differences, the Tribunal concludes that Israel's rule over the Palestinian people, wherever they reside, collectively amounts to a single integrated regime of apartheid. ${ }^{7}$

The UN Security Council adopted a series of resolutions imposing sanctions against the apartheid state of South Africa in the 1970s. Resolution $392^{8}$, adopted in June 1976, strongly condemned the Apartheid regime for resorting to massive violence against its people and called on South Africa to end racism and racial discrimination. One of the two resolutions which the Council passed the following year, Resolution $417^{9}$ of October 1977, demanded, inter alia, that the South African regime should abolish the policy of apartheid. Resolution $418^{10}$ of November 1977 went beyond the two by thrusting military sanctions upon South Africa on the ground that its apartheid policies, violence and acquisition of weapons were a threat to international peace and security. The UN Security Council's engagement with the apartheid regime continued in the 1980s. One of such resolutions, Resolution $569^{11}$, adopted in July 1985, condemned the state of emergency and imposed partial economic sanctions against this state. The Council thus indicated its view that apartheid was a threat to international peace and security, precisely because such a system of racial segregation and discrimination could not possibly be sustained without violence and repression (Dugard and Reynolds 2013: 880). Apartheid is a crime against humanity and constitutes a breach of obligations erga omnes. It therefore amounts to an international crime. It can be argued that Israel is likewise an apartheid state. It is therefore in breach of the most fundamental norms of international law and human rights. If so, similar sanctions ought to be employed by the UN Security Council against Israel.

Akram suggests that the Palestinian strategy could also benefit from the experience of the strategies designed to use the UN platform for facilitating the independence of Namibia (formerly, South West Africa) which was under South Africa's military occupation before its decolonization. This strategy involved the request of certain actors for an advisory opinion before the International Court of Justice concerning the South African presence in South West Africa. This process was then taken up by the UN (led by the General Assembly) to affirm the right of Namibian independence and impose sanctions on South Africa. The UN Security Council, under pressure from a series of opinions by the Court, eventually came to institute sanctions against South Africa in 1977, inter alia, on this ground. The UN also instituted mechanisms in order to lead the way for Namibia's independence from South Africa which eventually materialized in 1990. Such concerted legal strategies could be deployed too for the independence struggle of the Palestinians (Akram 2011).

\section{The Oslo Process and Critical Scholars}

Critical scholars have mostly adopted a euphemistic view of the Oslo Peace Process which was set in motion with the Oslo Agreement of 1993 that brought the Israeli and Palestinian sides together. ${ }^{12}$ The negotiation process leading to Oslo witnessed the Palestinian 
leadership's acceptance of the Israeli condition to shun from endeavouring to get support from international institutions. This meant that Palestinians would avoid any attempt at mobilizing the UN Security Council against Israeli aggression. In the words of Rouhana, "history and justice were permanently excluded from the negotiating process" (Rouhana 2018: 646). Indeed, Oslo represents a triumph for the Israeli strategy of marginalizing Palestinians and their claims on the one hand, and, on the other, garnering greater international support, gaining greater credibility, and the broadening of options for Israeli diplomacy. Absent from the Oslo arrangement were terms that were essential to the Palestinian liberation, such as "occupation, self-determination, sovereignty, statehood, return, decolonization" (Rabbani 2013: 29).

However by romanticising about the "peace process" and exaggerating its potency, critical scholars tended to play down its asymmetrical character and its failure to embody, without ambiguity, the Palestinian rights and entitlements as markers of independent statehood. ${ }^{13}$ When referring to the Oslo process, Edward Said bitterly criticises the Israeli strategy of glossing over the hard truth about the history of Palestinian suffering and losses caused by the Zionist ideology. According to Said, Israel's domineering posture - which fully featured in Oslo - amounted to a denial of an essential part of Palestinian identity. This is what he says about the drama of Oslo:

Why must we forget our history of sacrifice? Why must we remain silent about reparations and restitution during negotiations that virtually require us to give up our own identity, just to satisfy the paranoid demands of Israel's security obsession? (Said 2011: 69-70).

Israel's recognition of the PLO (Palestinian Liberation Organization) was about the only tangible gain made by the Palestinians in Oslo. Other than that, the Palestinian negotiators accepted the postponement of discussions about the issues of boundaries and sovereignty until the "final Status negotiations". This meant that, the Palestinians, rather than possessing any legal entitlement to the West Bank and Gaza as "occupied territories", would have to negotiate over these "disputed territories" in the future (Said 2013: 18). Although Oslo actually represented the burial of Palestinian claims, most of the critical scholars - albeit some critical scholars were thoroughly displeased with the Oslo Agreement and other accords adopted later - continued to treat it as a promising text which would carry the Palestinians along the path of independence. They have mostly failed to conceptualise ideas and formulations which could provide better terms of settlement for Palestinians than those offered by Israel and the US. Today, large number of critical scholars continues to pay lip service to the "two-state solution" although, Oslo, because of Israel's refusal to apply the agreement, has simply become a thing of the past. One could easily discern the failure of most critical scholars - and international institutions such as the UN - to call for collective and comprehensive sanctions against Israel by the UN Security Council in order to stem the tide of Israeli aggression, its unceasing land grabbing in the West Bank (including Jerusalem), its building of illegal settlements in the occupied territories, its construction of the so-called "Security Wall" in the West Bank, and its ongoing segregationist policies. 


\section{Treating Israel as a "Normal" State}

The aforementioned discussions should lead us to conclude that it is indeed anomalous to treat Israel as a "normal" state. This is particularly related to its settler-colonial nature, its racist/segregationist character, its unbridled desire and determination to expand its territory by illegal means, and its aversion to establish peaceful relations with its neighbours. Israel is not a liberal democratic state in the universal sense nor is it a non-racial and egalitarian state that relies on equality before law and non-discrimination. The new nation-state law which the Israeli parliament enacted as a Basic Law in July 2018 has officially reaffirmed the racist character of the state by privileging Jews against all other enthnic and/or religious groups in Israel. In terms of state-society relations, Israel is not less aggressive than the former Apartheid South Africa which was - from the 1970s - treated by international society (specifically by the UN) as a pariah state. Therefore, the same approach should also apply to Israel which means that it should not be treated as a "normal member" of international society today. The hard truth is that "the Israeli paradigm is a colonialist and post-colonialist mixture, a political outfit of a settler state ruling through a Mukhabarat state" (Pappé 2011: 272). If Israel were to be seen for what in fact it is, namely a colonialist state that is responsible for the dispossession of the Palestinians and the occupation of their homeland, international society would possibly have exerted greater pressure to bear on it in order to force a change of behaviour towards the Palestinians as well as its predominantly Arab neighbours.

Israel is among the most militarized and jingoist states in the world; as such, it is not only a threat to regional peace, but also a threat to global political stability. The Zionist state has flatly rejected all sorts of Arab peace initiatives that would end mutual hostilities with relatively little sacrifice on its part. It is alarming that both the Israeli state and a considerable portion of its Jewish citizens have come to see war, conflict and violence as the most viable option for their state to survive, because violent strategies guarantee the superiority and hegemony of Israel over its adversaries. Israel, then, is the epitome of a deeply militaristic state that has an aversion to peace and reconciliation (Halper 2015: 38). Its militaristic ethos and Zionist political culture - which is dismissive of ethics in international relations - appears to be the main markers of its foreign relations. Indeed, during the Cold War, Israel acted as the main ally and arms supplier of some of the most repressive regimes in the world such as the Apartheid South Africa and Pinochet's Chile (Shahak 1982: 15). ${ }^{14}$ Israel's disregard for peace and morality in its international relations has persisted after the Cold War. ${ }^{15}$

The global "War on Terror" discourse - that followed the September 11 attacks of 2001 - resulted in jingoist/militarist states such as the US and Israel obtaining the tacit support of the UN Security Council. As such, the tragic September 11 attacks have been manipulated by the US and Israel to legitimize their aggressive actions (e.g. the American invasion of Iraq in 2003 and the Israeli invasion of Lebanon in 2006) in public and scholarly discourse. These military interventions have been disastrous for peace and stability of the Middle East and specifically for Palestinians. ${ }^{16}$ Israel's oppression of (and attacks to) Palestinians living within and beyond its borders intensified after September 11 attacks. Successive Israeli governments claimed that their conflict with the Palestinian armed 
resistance was part of the US-led global "War on Terror". The intensification of Israeli aggression could be seen in the cases of numerous assassinations of Palestinian leadership across the Middle East, an all-out assault on Gaza and Lebanon with devastating human and physical consequences, unlawful killings of Palestinians by security forces, aerial operations against states like Syria and Sudan, a new spree of illegal settlements in the West Bank (including Jerusalem), and the building of a "Security Wall" traversing the entire West Bank. As such, there is ample scope to argue that, being one of the most jingoist/aggressive states in the world, Israel has acted in constant breach of the conditions for its acceptance as a member of the UN in 1949. Therefore, as stipulated in Article 6 of the UN Charter, Israel can be - and should be - expelled from the UN membership if the international community were to adhere to universal standards of international law.

\section{The Drama of Palestinian Scholars}

Perhaps not surprisingly, it is often the Palestinians themselves, as the prime victims of Israeli aggression and colonization, who have sought to bring in new ideas and challenge the sterility of the discourse and narratives about their problem. It has been mostly the Palestinian scholars and activists who have cried out against confining the Israeli-Palestinian problems to the parochial terrains of the occupied West Bank and Gaza (captured in 1967). Many of them relate the Palestinian tragedy conceptually to the settler-colonialism of the Zionist ideology, while others endeavour to expand the scope of the debate to encompass the right to self-determination for the entirety of the original inhabitants of the former Mandate of Palestine.

The settler-colonial structure of Israel in this post-colonial age is well captured by a group of Palestinian scholars who identify certain Israeli acts as expansionist, violent, racist and dehumanizing: "aerial and maritime bombardment, massacre and invasion, home demolitions, land theft, identity card confiscation, racist laws and loyalty tests, the wall, the siege on Gaza, cultural appropriation" (Salamanca et al. 2012: 2). Israel does all this under the protective gaze of certain imperialist actors such as the US (Salamanca et al. 2012: 2). In addition to the imperialist shelter benefiting Israel, neither regional nor global actors have displayed a substantial commitment to prevail over or at least constrain Israel. International society and international institutions such as the UN appear to have abandoned the Palestinians, while the Muslim-majority countries, both individually and collectively, have tended to do very little beyond verbal condemnations of Israel. It is therefore difficult to disagree with Yezid Sayigh, a prominent scholar on the Middle East, when he complains that the Palestinians are left alone:

[T] he Palestinians need to take the initiative. They need to push on national unity, they need to push at the UN, they need to push countries like the United Kingdom and others to step up at least to that minimal threshold, in order to change some of the dynamics because no one else is going to change it for them. ${ }^{17}$ 


\section{Conclusion}

The existing scholarly literature on the Israel-Palestinian problem, including the bulk of critical scholars who sympathise with the Palestinians as victims, appears to be constrained in its scope and reach mainly by three factors: first, the power politics framework within the existing world order dominated by the US is strongly bent against the delivery of a fair solution to the Palestinian problem in our present time; second, international institutions and decision-making mechanisms dealing with this problem, such as the UN, have not sufficiently utilised the potential of international law within which the Palestinian problem and the terms for its peaceful solution are defined; thirdly, scholars and observers dealing with the Palestinian problem appear to have been strongly influenced by the global reach of the Zionist lobby, the immunity enjoyed by Israel as the "sacred cow" of the global system, the peer group pressure, and by conventions of power politics which has been manifest, inter alia, in their resignation to only a partial solution to the Palestinian problem. Hence, with few exceptions, the academic discourse on the Israeli-Palestinian problem is astonishingly status quo oriented and mostly devoid of imaginative prescriptions.

The literature on the Palestinian problem, then, needs to be reinvigorated by academics and writers who should face up to the reality of the full force, brutality and devastating consequences of the Zionist project and suggesting solutions based on a comprehensive notion of Palestinian self-determination. Therefore, committed critical/progressive scholars are well advised to keep alert about the threat of Palestinian extinction at the hands of the ongoing Zionist settler-colonial project. This suggests that there are two concepts which are the keys to the solution of the Palestinian problem: "decolonisation" and "liberation". This analytical framework rejects assumptions about Israel's exceptionalism (a sort of privileged status as a victim of the Nazi Holocaust) and instead places it alongside other instances of settler-colonialism, as in the cases of Rhodesia, South Africa and French Algeria. After all, the Palestinians were not the ones to victimize the Jewish people during the Nazi-led Holocaust in Europe; therefore, they should not be the ones to bear the bitter consequences of such a tragic past. Another feature of "new scholarship" on Israel should be to demonstrate the falsity/weakness of considering Israel as an example of European liberal democracy (Salamanca et al. 2012: 4).

Limited and partial as they are, nonetheless, a number of rights and entitlements have been accorded to the Palestinians through a series of international mechanisms over the years, which include the UN Security Council Resolutions $242^{18}$ (1967) and $338^{19}$ (1973) demanding the Israeli withdrawal from the Palestinian territories occupied in 1967, the UN General Assembly Resolutions, first and foremost the Resolution $194^{20}$ (1948) which recognizes the Palestinian refugee rights, and a long list of other international declarations, resolutions and decisions passed by the UN, Islamic Cooperation Organization, the NonAligned Movement and others condemning illegal Jewish settlements in the occupied territories, unceasing military aggression, Israel's arbitrary killing of Palestinians, territorial annexations, the building of the so-called "Security Wall" in the West Bank, and Israeli war crimes and crimes against humanity. All these suggest that any terms of settlement between Israel and the Palestinians which retract from the fundamental and most essential Palestinian rights and entitlements as recognized by international law, society and institutions would be 
a breach of peremptory norms of international law, of the Palestinians' right to selfdetermination, as well as a breach of justice and fairness in international law. A tedious and routinized preaching of loyalty to the "two state solution" like a mantra, as has been done by several international institutions, states and scholars, although the territories under which the Palestinian state is supposed to be established are either gradually being annexed into Israel (West Bank-East Jerusalem) or are under a deadly siege (Gaza), is not only misleading, but also morally suspect. The time has come for the scholarly discourse relating to the IsraeliPalestinian problem to face up to the breadth and depth of Palestinian victimhood and to recognize the potent role the UN and other international organizations could assume, at least, via imposing comprehensive economic sanctions and diplomatic isolation targeting Israel.

\section{Notes}

1. On Israel's massive human rights violations, war crimes and crimes against humanity with regard to the Palestinians, see the report by Human Rights Watch, 'Israel: 50 Years of Occupation Abuses', 4 June 2017, https://www.hrw.org/news/2017/06/04/israel-50years-occupation-abuses; Advisory Opinion of the International Court of Justice on the separation wall built by Israel in the West Bank, Legal Consequences of the Construction of a Wall in the Occupied Palestinian Territory, 9 July 2004, https://www.icjcij.org/files/case-related/131/131-20040709-ADV-01-00-EN.pdf; Report of the UN Secretary-General, 'Israeli settlements in the Occupied Palestinian Territory, including East Jerusalem, and the occupied Syrian Golan', 24 August 2016, https://documents-ddsny.un.org/doc/UNDOC/GEN/N16/267/89/PDF/N1626789.pdf?OpenElement; on the devastating human consequences of Israel's deadly blockade against the people of Gaza since 2007 and its all-out ruthless attack against Gaza in December 2008-January 2009, see the 'Report of the United Nations Fact-Finding Mission on the Gaza Conflict' (commonly known as 'Goldstone Report'), 25 September 2009, https://www2.ohchr.org/english/bodies/hrcouncil/docs/12session/A-HRC-12-48.pdf); in May 2018, the state of Palestine submitted a complaint before the International Criminal Court for possible investigation against certain individuals in relation to Israel's human rights crimes against Palestinians. On this, see 'Preliminary Examination: Palestine', International Criminal Court, https://www.icc-cpi.int/palestine.

2. UN General Assembly Resolution No. 181, 29 November 1947, http://daccess-ddsny.un.org/doc/RESOLUTION/GEN/NR0/038/88/IMG/NR003888.pdf?OpenElement.

3. On this, see Robert Cox, "Gramsci, hegemony and international relations: An essay in method", in Stephen Gill (Ed.), Gramsci, Historical Materialism and International Relations, Cambridge, Cambridge University Press, 1993, 49-66.

4. Rouhana compares and contrasts two prominent scholars with some views about a workable framework for a solution. In fact both of them try to work out some formulations that do not pose any real challenge to the status quo, as defined by Israel (Rouhana 2018: 652). 
5. What Next for the Middle East Peace Process?, Transcript: Q \&A, The Royal Institute of International Affairs, 28 May 2014, https://www.chathamhouse.org/sites/default/files/field/field_document/20140528MiddleE astPeaceProcessQ\&A.pdf.

6. UN General Assembly Resolution No. 3379, 10 November 1975, https://documents-ddsny.un.org/doc/RESOLUTION/GEN/NR0/000/92/IMG/NR000092.pdf?OpenElement.

This resolution was rescinded in 1991 although Israel's racist policies intensified after the Cold War.

7. Russell Tribunal on Palestine, 'Findings of the South Africa Session', 5-7 November 2011, http://www.russelltribunalonpalestine.com/en/sessions/south-africa/south-africasession-\%E2\%80\%94-full-findings.

8. Resolution 392, $19 \quad$ June 1976 , http://www.un.org/en/ga/search/view_doc.asp?symbol=S/RES/392 (1976).

9. Resolution 417, $31 \quad$ October 1977 , http://www.un.org/en/ga/search/view_doc.asp?symbol=S/RES/417 (1977).

10. Resolution 418, 4 November http://www.un.org/en/ga/search/view_doc.asp?symbol=S/RES/417 (1977).

11. Resolution $569, \quad 26 \quad$ July $1985, \quad$ https://documents-ddsny.un.org/doc/RESOLUTION/GEN/NR0/488/97/IMG/NR048897.pdf?OpenElement.

12. The series of texts constituting the legal basis of the Oslo peace process consist of the following: Declaration of Principles on Interim Self-Government Arrangements ('Oslo Agreement'), 13 September 1993, http://www.refworld.org/docid/3de5e96e4.html; GazaJericho Agreement, Annex IV, Protocol on Economic Relations between the Government of the State of Israel and the P.L.O., representing the Palestinian people, Paris, April 29, 1994, https://israelipalestinian.procon.org/sourcefiles/1994ParisProtocol.pdf; IsraeliPalestinian Interim Agreement on the West Bank and the Gaza Strip, Washington, D.C., September 28, 1995, https://ecf.org.il/media_items/624; The Wye River Memorandum, October 23, 1998, https://peacemaker.un.org/sites/peacemaker.un.org/files/IL\%20PS_981023_The\%20Wye \%20River\%20Memorandum.pdf.

13. As The National editor put it in 2013, 'Amid the boisterous enthusiasm of September 1993, a few warning voices could be heard, just barely.' (The National, 14 September 2013, https://www.thenational.ae/world/time-disproves-oslo-optimism-of-20-years-ago1.265993.

14. Also see, Benjamin Beit-Hallahmi, The Israeli Connection: Whom Israel Arms and Why, (New York: Pantheon, 1987), p. XII. Among such regimes were - dictator - Somoza's Nicaragua, Apartheid South Africa, and the Shah's Iran.

15. On this, see, for instance, Richard Becker, Palestine, Israel and the U.S. Empire (PSL Publications, 2013); James Petras, The Politics of Empire: The US, Israel and the Middle East (Clarity Press, 2014).

16. On this subject, see Berdal Aral, 'An Inquiry into the 'Effective' United Nations Security Council Resolutions Relating to the Middle East', Muslim World, Vol. 102 (2012), pp. 225-247. 
17. What Next for the Middle East Peace Process?, Transcript: Q \&A, Chatham House, 28

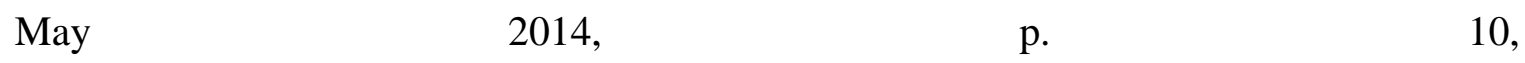
https://www.chathamhouse.org/sites/default/files/field/field_document/20140528MiddleE astPeaceProcessQ\&A.pdf.

18. UN Security Council Resolution No. 242, 22 November 1967, http://www.un.org/ ga/search/view_doc.asp?symbol=S/RES/242 (1967).

19. UN Security Council Resolution No. 338, 22 October 1973, http://www.un.org/en/ga/search/view_doc.asp?symbol=S/RES/338 (1973).

20. UN General Assembly Resolution No. 194, 11 December 1948, https://unispal.un.org/DPA/DPR/unispal.nsf/0/C758572B78D1CD0085256BCF0077E51

A.

\section{References}

Advisory Opinion of the International Court of Justice, Legal Consequences of the Construction of a Wall in the Occupied Palestinian Territory, 9 July 2004, https://www.icjcij.org/files/case-related/131/131-20040709-ADV-01-00-EN.pdf.

Akram, Susan, (2011) 'The Palestinian Statehood Strategy in the United Nations: Lessons from Namibia', Jadaliyya, http://www.jadaliyya.com/Details/24468/The-PalestinianStatehood-Strategy-in-the-United-Nations-Lessons-from-Namibia.

Aral, Berdal (2012) 'An Inquiry into the 'Effective' United Nations Security Council Resolutions Relating to the Middle East' Muslim World 102, pp. 225-247.

Becker, Richard (2013) Palestine, Israel and the U.S. Empire (PSL Publications: San Francisco).

Beit-Hallahmi, Benjamin (1987) The Israeli Connection: Whom Israel Arms and Why (New York: Pantheon).

Bourdieu, Pierre and Wacquant, Loïc (1999) 'On the Cunning of Imperial Reason' Theory, Culture \& Society 16, pp. 41-58.

Carty, Anthony (2013) 'Israel's Legal Right to Exist and the Principle of the Selfdetermination of the Palestinian People?' The Modern Law Review, 76 (1), pp. 158-177.

Chimni, B. S. (2006) 'Third World Approaches to International Law: A Manifesto' International Community Law Review 8, pp. 3-27.

Cox, Robert (1993) 'Gramsci, hegemony and international relations: An essay in method', in Stephen Gill (ed.) Gramsci, Historical Materialism and International Relations (Cambridge: Cambridge University Press), pp. 49-66.

Declaration of Principles on Interim Self-Government Arrangements ('Oslo Agreement'), 13 September 1993, http://www.refworld.org/docid/3de5e96e4.html. 
Dugard, John and Reynolds, John (2013) 'Apartheid, International Law, and the Occupied Palestinian Territory' The European Journal of International Law 24 (3), pp. 867913. $2-10$.

Esmeir, Samera (2004) 'Introduction: In the Name of Security' Adalah's Review 4, pp.

Garaudy, Roger (1996) The Founding Myths of Israeli Politics (AAARGH).

Gaza-Jericho Agreement, Annex IV, Protocol on Economic Relations between the Government of the State of Israel and the P.L.O., representing the Palestinian people, Paris, 29 April 1994, https://israelipalestinian.procon.org/sourcefiles/1994ParisProtocol.pdf.

Halper, Jeff; Johnson, Jimmy and Schaeffer, Emily (2009) The Israeli-Palestinian Conflict: Challenging Slogans through Critical Reframing, Report by the Israeli Committee Against House https://web.stanford.edu/group/sper/images/SlogensRhetoric.pdf.

Halper, Jeff (2015) War against the People: Israel, the Palestinians and Global Pacification, (London: Pluto Press).

Human Rights Watch, 'Israel: 50 Years of Occupation Abuses', 4 June 2017, https://www.hrw.org/news/2017/06/04/israel-50-years-occupation-abuses.

International Criminal Court, 'Preliminary Examination: Palestine', 22 May 2018, https://www.icc-cpi.int/palestine.

Israeli-Palestinian Interim Agreement on the West Bank and the Gaza Strip, Washington, D.C., 28 September 1995, https://ecf.org.il/media_items/624.

Massad, Joseph A. (2006) The Persistence of the Palestinian Question: Essays on Zionism and the Palestinians (New York: Routledge).

Mearsheimer, John J. and Walt, Stephen M. (2008) The Israel Lobby and US Foreign Policy (London: Penguin Books).

Pappé, Ilan (2011) The Forgotten Palestinians: A History of the Palestinians in Israel (New Haven and London: Yale University Press).

Petras, James (2014) The Politics of Empire: The US, Israel and the Middle East (Clarity Press: Atlanta).

Quigley, John (2005) The Case for Palestine: An International Law Perspective (Durham \& London: Duke University Press).

Rabbani, Mouin (2013) 'Twenty Years of Oslo and the Future of the Two-State Paradigm' Perspectives 5, pp. 29-32.

Rajagopal, Balakrishnan (2006) 'Counter-Hegemonic International Law: Rethinking Human Rights and Development as a Third World Strategy' Third World Quarterly 27 (5), pp. 767-783. 
Report of the UN Secretary-General, 'Israeli settlements in the Occupied Palestinian Territory, including East Jerusalem, and the occupied Syrian Golan', 24 August 2016, https://documents-dds-

ny.un.org/doc/UNDOC/GEN/N16/267/89/PDF/N1626789.pdf?OpenElement.

'Report of the United Nations Fact-Finding Mission on the Gaza Conflict' (commonly known as 'Goldstone Report'), 25 September 2009, https://www2.ohchr.org/english/bodies/hrcouncil/docs/12session/A-HRC-12-48.pdf.

Rouhana, Nadim N. (2018) 'Decolonization as reconciliation: rethinking the national conflict paradigm in the Israeli-Palestinian conflict' Ethnic and Racial Studies 41 (4), pp. 643-662.

Russell Tribunal on Palestine, 'Findings of the South Africa Session', 5-7 November 2011, http://www.russelltribunalonpalestine.com/en/sessions/south-africa/south-africasession-\%E2\%80\%94-full-findings.

Said, Edward (1979) The Question of Palestine (New York: Vintage).

Said, Edward (1979) 'Zionism from the Standpoint of Its Victims' Social Text 1, pp. 758.

Said, Edward (2011) 'Edward Said's Lost Essay on Jerusalem: The Current Status of Jerusalem', Introduction by Rashid Khalidi Jerusalem Quarterly 45, pp. 57-72.

Said, Edward (2013) 'The Morning After’ Perspectives 5, pp. 15-22.

Salamanca, Omar Jabary; Qato, Mezna; Rabie, Kareem and Samour, Sobhi (2012) 'Past is Present: Settler Colonialism in Palestine' Settler Colonial Studies 2 (1), pp. 1-8.

Shahak, Israel (1982) Israel's Global Role: Weapons for Repression (Belmont, MA: Association of Arab-American University Graduates).

Slater, Jerome (2007) 'Muting the Alarm over the Israeli-Palestinian Conflict: The New York Times versus Haaretz, 2000-06’ International Security 32 (2), pp. 84-120.

The National, 14 September 2013, https://www.thenational.ae/world/time-disprovesoslo-optimism-of-20-years-ago-1.265993.

The Wye River Memorandum, 23 October 1998, https://peacemaker.un.org/sites/peacemaker.un.org/files/IL\%20PS_981023_The\%20Wye\%20 River\%20Memorandum.pdf.

UN General Assembly Resolution No. 181, 29 November 1947, http://daccess-ddsny.un.org/doc/RESOLUTION/GEN/NR0/038/88/IMG/NR003888.pdf?OpenElement.

UN General Assembly Resolution No. 194, 11 December 1948, https://unispal.un.org/DPA/DPR/unispal.nsf/0/C758572B78D1CD0085256BCF0077E51A.

UN General Assembly Resolution No. 3379, 10 November 1975, https://documentsdds-ny.un.org/doc/RESOLUTION/GEN/NR0/000/92/IMG/NR000092.pdf?OpenElement. 
UN Security Council Resolution No. 242, 22 November 1967, http://www.un.org/ga/search/view_doc.asp?symbol=S/RES/242 (1967).

UN Security Council Resolution No. 338, 22 October 1973, http://www.un.org/en/ga/search/view_doc.asp?symbol=S/RES/338 (1973).

UN Security Council Resolution No. 392, 19 June 1976, http://www.un.org/en/ga/search/view_doc.asp?symbol=S/RES/392 (1976).

UN Security Council Resolution No. 417, 31 October 1977, http://www.un.org/en/ga/search/view_doc.asp?symbol=S/RES/417 (1977).

UN Security Council Resolution No. 418, 4 November 1977, http://www.un.org/en/ga/search/view_doc.asp?symbol=S/RES/417 (1977).

UN Security Council Resolution No. 569, 26 July 1985, https://documents-ddsny.un.org/doc/RESOLUTION/GEN/NR0/488/97/IMG/NR048897.pdf?OpenElement.

Varol, Ahmet (2009) Filistin Hakkında Yanılgllar (İstanbul: Beka).

Welty, Gordon A. (1984) 'Israel: Between Colonialism and Imperialism' The Antioch Review 42 (1), pp. 60-76.

What Next for the Middle East Peace Process?, Transcript: Q \&A, The Royal Institute $\begin{array}{lllll}\text { of International } & \text { Affairs, } & 28 & \text { May }\end{array}$ https://www.chathamhouse.org/sites/default/files/field/field_document/20140528MiddleEast PeaceProcessQ\&A.pdf.

Zureik, Elia (2016) Israel's Colonial Project in Palestine (London \& New York: Routledge).

\begin{abstract}
About the Author
Professor Berdal Aral is currently a lecturer at the Department of International Relations, Istanbul Medeniyet University in Turkey. His research interests are presently focused on the Palestinian problem, disunity within the Muslim world, and the hegemonic aspects of international law and institutions.
\end{abstract}

